Koedoe 17: 39 - 69 (1974).

\title{
SURVEY OF THE ADEQUACY \\ OF EXISTING CONSERVED AREAS IN RELATION TO WILD ANIMAL SPECIES
}

\author{
W. VON RICHTER* \\ Mammal Research Institute \\ University of Pretoria
}

Pretoria

0001

Abstract - The following mammals larger than the silver fox (Vulpes chama) were considered to be endangered within South and South West Africa - Cape mountain zebra (Equus zebra zebra); Hartmann's mountain zebra (Equus zebra hartmannae); black rhinoceros (Diceros bicornis); reedbuck (Redunca arundinum); red lechwe (Kobus leche); puku (Kobus vardoni) - probably extinct in South Africa; sable (Hippotragus niger); roan antelope (Hippotragus equinus); bontebok (Damaliscus dorcas dorcas); tssessebe (Damaliscus lunatus); black-faced impala (Aepyceros melampus petersi); oribi (Ourebia ourebi); suni/Livingstone's antelope (Neotragus moschatus); pangnlin (Manis temminckii); leopard (Panthera pardus); cheetah (Acinonyx jubatus); brown hyaena (Hyaena brunnea). The following birds were considered to be endangered - Jackass penguin (Spheniscus demersus); pink-backed pelican (Pelecanus rufescens), white pelican (Pelecanus onocrotalus); bald ibis (Geronticus calvus); lammergeyer (Gypaëtus barbatus).

The following large reptiles were considered endangered - Nile crocodile (Crocodylus niloticus); loggerhead turtle (Caretta caretta); leatherback turtle (Dermochelys coriacea). The following large mammals were considered to be rare within South and South West Africa - Square-lipped rhino (Ceratotherium simum simum) - rare, but secure; nyala (Tragelaphus angasi) - rare, but secure; sitatunga (Tragelaphus spekei); blue duiker (Cephalophus monticola); red duiker (Cephalophus natalensis); vaal rhebuck (Pelea capreolus); black wildebeest (Connochaetes gnou) - rare, but secure; klipspringer (Oreotragus oreotragus); Cape grysbok (Raphicerus melanotis); Sharpe's grysbok (Raphicerus sharpei); lion (Panthera leo); aardvark (Orycteropus afer); spotted hyena (Crocuta crocuta); hunting dog (Lycaon pictus); Cape fur seal (Arctocephalus pusillus); eland (Taurotragus oryx); hartebees (Alcelaphus buselaphus); samango monkey (Cercopithecus mitis) - not common, but secure as long as adequate habitat is protected.

*Present address:Dept. of Wildlife and National Parks, P.O. Box 131, Gaborone, Botswana. 


\subsection{Introduction}

The terms of reference for this survey stipulated by the IBP National Committee through the CT Working Group were:

"To determine the adequacy of existing conserved areas in relation to wild animal species, and to make recommendations in the light of the information obtained to ensure the survival of species at present in danger of extinction".

The CT Working Group subsequently decided that only mammals above the size of the silver fox (Vulpes chama) should be actively surveyed, but that any relevant information on other animal species and their survival status which was readily available should be included in the report.

The survey was initiated in May 1968 and the field work completed in December 1970. It became evident that information on the status and distribution of species outside conservation areas was essential for a reasonable assessment of their survival status. Such information was partially available from Natal, the Transvaal and the Cape Province. As no detailed information on abundance and distribution of large mammalian species in the Orange Free State was on hand, a survey of game on farmland in the Orange Free State was carried out through the post during 1970.

\subsection{Methods}

Visits were paid to all relevant provincial nature and game reserves, National Parks, to conservation areas under the control of the Department of Forestry and to a number of selected private and municipal reserves, thus augmenting the available published and unpublished information with first-hand observation.

For each conservation area investigated, a standard IBP CT Check Sheet was completed as laid down by Peterken (1967) and Nicholson (1968). Peterken (1967) has provided the following definitions for two terms used in this report:

rare: species or subspecies which are rare in the region containing the IBP area ( = conserved area), but not necessarily rare elsewhere;

threatened or endangered: species or subspecies which are rare when considered on a world-wide scale.

The "Region" under consideration here was the Republic of South Africa and South West Africa. Information on the survival status of certain mammal species in South West Africa has been included for the sake of completeness. In considering the present status of species in the Republic, the former distribution and habitat requirement of the species concerned was borne in mind. Mammal species not discussed in detail here are considered not to be rare or endangered in South Africa although 
almost entirely confined to conservation areas included the following large species: elephant, hippopotamus, buffalo, eland, blue wildebeest, hartebeest, gemsbok, waterbuck, giraffe and Burchell's zebra. Impala, springbok, blesbok, kudu, bushbuck, steenbok, duiker, mountain reedbuck and vaal rhebuck, warthog and bush pig are still to be found in appreciable numbers on farmland with suitable habitat.

\subsection{Rare and endangered mammal species}

\section{Samango monkey (Cercopithecus mitis)}

The preferred habitat of this species - dense forest - limits its distribution and abundance in South Africă. It occurs in reasonable numbers in all forest areas in the eastern Cape, Natal and Zululand, and in the eastern and northeastern Transvaal. As long as the forest areas fall under the jurisdiction of the Department of Forestry or any other nature conservation authority, no concern for the survival of the species is expressed. Outside of conserved areas, however, numbers of the species have decreased substantially due to heavy hunting by local inhabitants and habitat destruction, especially in northern Zululand.

Status: Secure as long as adequate habitat is protected.

\section{Cape mountain zebra (Equus zebra)}

The only permanent sanctuary for the species is the Mountain Zebra National Park near Cradock, Cape Province. In April 1971, the population in this reserve numbered 127. A further six animals ( 3 males, 2 females and 1 foal) are kept on the De Hoop Provincial Nature Reserve and Millar $(1968,1970 a)$ has estimated the number of free ranging mountain zebra at 39, spread over the Gamka, Kamanassie, Outeniqua and Kouga Mountains in small groups.

The species is endangered as the only viable population is concentrated in one reserve and could easily be decimated by the outbreak of a disease. It is essential for the survival of the species that a second sanctuary be established as soon as possible and the remaining wild specimens transferred to it. Otherwise it could only be a matter of time before the species is exterminated.

The Nature Conservation Department of the Cape Province is in the process of acquiring suitable areas for a sanctuary in the Gamka Mountains. A concentrated effort should be made by all nature conservation authorities to speed up the creation of the second sanctuary. It is suggested that a joint effort should be made by the Cape Provincial Administration and the National Parks Board of Trustees, as administrators of the Mountain Zebra National Park, to secure the preservation of the species.

Statis: Endangered 
Though the taxonomical situation as a distinct subspecies is now questioned (Heinichen 1970), this is still treated as different from the Cape mountain zebra.

Recent estimates put the total number as 7000 of which 4000 are found on farmland as against 10500 on farmland alone in 1960 (Van der Spuy 1962). An estimated 500-800 have found refuge in a reserve in the Naukluft Range in the Maltahöhe District in the southern part of South West Africa. The Namib Desert Park harbours a small migratory population in marginal habitat. The largest concentration is found in the Khomas Hochland and approximately 1200 animals live in the Kaokoveld near the Cunene River.

The Naukluft Mountain Zebra Park is no ecological unit, as permanent water is lacking, and is not viable as a sanctuary. The population in the Kaokoveld is endangered by the envisaged development of the area as a Bantu homeland. The populations on farmlands are not secure as hunting permits are issued in times of drought when zebra compete with domestic stock for grazing and water. Illegal hunting is quite common as hides find a ready market and zebra meat is used as rations for native labourers.

The situation gives cause for alarm and additional measures are necessary to ensure the ultimate survival of the species. The most logical and reasonable solution would be the extension of the Naukluft Mountain Zebra Park, thus making it a viable ecological unit. The whole Naukluft Range is an uneconomical farming area and could be turned to better use as a conservation area. In addition, the area could be linked up with the Namib Desert Park, to create a unique conservation area which would stretch from the coast to the escarpment. A sanctuary in the Kaokoveld would benefit not only the mountain zebra, but also the black rhinoceros, as will be pointed out, and would preserve an area of almost unsurpassable beauty.

Status: endangered

\section{Square-lipped rhinoceros (Ceratotherium simum simum)}

The southern square-lipped rhinoceros, once on the brink of extinction, has recovered remarkably well and has been re-introduced in many areas within its known former range.

The stronghold of the species is the Umfolozi-Hluhluwe-Corridor complex where, in 1969, at least 1208 were counted (Vincent pers. comm.). This does not include animals in the adjacent Bantu Reserve, estimated at 394 in 1968 (Vincent 1969). The Ndumu Game Reserve harboured 25 animals in 1970 and nine animals are to be found in the Mkuzi Game Reserve, both representing re-introductions. The Queen Elizabeth Park Nature Reserve and Midmar Public Resort Nature Reserve have also recently been restocked with six animals each.

In the Kruger National Park the total population stands now at a minimum of 157 animals (Pienaar 1970). During the period $1961-1969$ 
139 animals were re-introduced (Anon. 1968, 1969, 1970a; Pienaar 1970). Further introductions have recently been made into various provincial, municipal and private game reserves in the Transvaal, Natal and the Orange Free State.

In the Transvaal 110 animals have been released since 1961. Approximately 20 are preserved in the Loskop Dam Nature Reserve, 16 having been introduced there (Anon. 1968, 1970a). Fifty-three occur on large private game reserves in the eastern Transvaal Lowveld (Anon. $1970 \mathrm{~b})$. The remainder is spread throughout the province. These large populations in the Transvaal have established themselves well, as indicated by the reported births from some of the reserves. In Natal 30 animals had been released on private land by 1970 (Anon. 1970a). The Willem Pretorius Game Reserve in the Orange Free State now harbours 16 animals, of which eight were introduced in 1965 (Anon. 1968).

The species has responded so well to the conservation efforts and measures adopted in the Zululand reserves that it has now become a problem to protect the available habitat from over-utilization in the most densely populated areas. Between 1961 and mid-1970, 701 surplus animals were removed from the Umfolozi-Hluhluwe complex by the Natal Parks Board (Anon. 1970b), but obviously the removal has to be increased further. If the removal of living animals cannot be stepped up, due to reasons of costs or declining demand for the species, and if the extension of the presently existing conservation areas is not feasible, more drastic measures will have to be adopted. Possibilities include reducing the competition of grazing species, coupled with habitat improvement and/or culling of the species.

Status: Rare but secure.

\section{Black rhinoceros (Diceros bicornis)}

The distribution of the species has drastically shrunk during the last century and is now confined to the following areas: Hluhluwe-Umfolozi-Corridor complex, with about 350 individuals (Hitchins 1968), Mkuzi and adjacent state land, with 30 - 40 animals, and the Ndumu Game Reserve, with 20 animals.

Joubert (1971b) estimated a total of 90 animals in the Etosha National Park and the Kaokoveld. Seventy per cent of the total population, however, inhabits areas which. will eventually be deproclaimed for development as a Bantu homeland. At present, approximately 25 animals have full protection in the newly delineated Etosha Pan National Park, after 19 animals were captured on farmland and transferred to the park.

Black rhinoceros have been re-introduced into the Addo Elephant National Park near Port Elizabeth and numbered eight in 1970. However, the animals are kept in an enclosure which is not ideal. The National Parks Board has also re-introduced the species into the Kruger National Park during 1972 . 
The overall position of the species is alarming. The populations in Hluhluwe and Umfolozi are merely maintaining themselves (Hitchins 1968; Roth and Child 1968; Joubert and Eloff 1971). It is apparent that the carrying capacity in these reserves has been reached or perhaps even exceeded. A large die-off of black rhinoceros in Hluhluwe has been attributed to over-population (Roth et al. 1968).

The populations in Ndumu and Mkuzi are small and expanding. However, with the high concentrations of other browsing species and the relatively small size of the areas, both populations will reach the ceiling of the habitat in the near future.

It is strongly recommended that a sanctuary be established in the Kaokoveld, where the highest concentration of the South West African black rhinoceros population is found. The extension of the Ndumu Game Reserve and the incorporation into the Hluhluwe and Umfolozi Game Reserves in Zululand of state land situated in the corridor between them would greatly help in the protection of the species. Management policies which would favour black rhinoceros habitat and remove competition from other browsing species are also essentiat. Child (1968) reports that black rhinoceros and other browsing species made use of the same plants on islands in Lake Kariba, suggesting considerable competition for food. Status: Endangered in South Africa.

\section{Nyala (Tragelaphus angasi)}

This is a tropical species which only extends into Zululand and the eastern Transvaal Lowveld within the boundaries of South Africa. It is abundant and over-abundant in all the Zululand reserves and has established itself well in the Kruger National Park in the northeastern sector, and has also colonized the riparian forests along the Shingwidzi-Mphongolo and Great Letaba Rivers further south (Pienaar 1963)

Small numbers have been reported from some farms in Zululand and in the northeastern Transvaal. The species has been introduced outside its former range into the Loskop Dam Nature Reserve (central Transvaal) and the Thabazimbi Private Nature Reserve (western Transvaal). The Natal Parks Board has sold a number of animals to farmers in Natal, for instance in the Pietermaritzburg district, also outside its former range, where they appear to be doing well (Mentis in litt.).

Though it is nearly extinct outside of conservation areas, except where specially protected by private individuals on their property, no concern for the survival of the species exists. The over-abundance in some Zululand reserves, however, makes it essential that management measures should be adopted to protect the habitat and thereby forestall a severe overpopulation.

Status: Rare, but secure. 


\section{Sitatunga (Tragelaphus spekei)}

The species has been recorded in the western Caprivi (Bigalke 1958; Tinley pers. comm.). No proclaimed conservation areas exist in this area. The preferred habitat of the species is the swampy areas. The fact that these areas are remote and inaccessible probably affords the sitatunga a certain amount of protection. However, it is strongly urged that a formal conservation area in the Caprivi, the only one possible in South West Africa, is set aside for the species.

Status: Rare.

\section{Blue duiker (Cephalophus monticola)}

A relict species, confined to dense evergreen indigenous vegetation from sea level to about $1300 \mathrm{~m}$ above sea level in Natal, Zululand and the southeastern Cape as far west as the Knysna forests (Bigalke and Bateman 1962; Vincent 1962). Records of the Department of Forestry indicate occurrence of the species in patches of mountain forest in the eastern Transvaal which have so far been undocumented. Where such forest patches are sufficiently protected, the blue duiker still occurs in fair numbers. Outside formally protected areas, however, the species has suffered a decline, mostly due to habitat destruction and poaching. The best measure to ensure the ultimate survival of the species, is the protection of the indigenous forests in South Africa.

Status: Rare.

\section{Red duiker (Cephalophus natalensis)}

Like the blue duiker, the red duiker is a relict species confined in South Africa to low-lying dense forests in the warm and humid regions of Natal (Bigalke 1967), the eastern Transvaal and the Zoutpansberg and Drakensberg Ranges (Kettlitz 1955).

It is adequately protected in the Zululand reserves and in reserves of the Department of Forestry in Zululand, as well as in the eastern Transvaal and escarpment. It has also been reported from the Timbavati Private Nature Reserve and the Groot Letaba Private Nature Reserve in small numbers in suitable habitat. The only suitable habitat in the Kruger National Park was unfortunately recently excised (Penzhorn 1969).

The best protection for the species would be the conservation of suitable habitat both within and outside of conservation areas. However, outside of conservation areas red duiker are decimated by illegal hunting by Bantu.

Status: Rare. 


\section{Vaal rhebuck (Pelea capreolus)}

An endemic species, mainly confined to the higher lying areas of the Cape Province, Natal, Orange Free State and the Transvaal, though it also has been reported from the Cape Point Nature Reserve, the De Hoop Provincial Nature Reserve, the Bontebok National Park and the Addo Elephant National Park, all at an altitude of $325 \mathrm{~m}$ above sea level, or lower. The species has found refuge in all the game and nature reserves in the Drakensberg, the escarpment of the eastern Transvaal and the abovementioned reserves in the Cape Province, as well as on some municipal reserves in this province.

Bigalke et al. (1962) estimate that approximately 10000 vaal rhebuck are to be found in the eastern and northeastern parts of the Cape Province. The total number is certainly higher as the southern and southwestern Cape has not yet been surveyed and the species occurs there as well, especially in areas under the protection of the Department of Forestry. In the Transvaal the species occurs especially around Waterberg in the west, around Ermelo, Wakkerstroom and Piet Retief in the southeast, around Lydenburg in the east and Pietersburg in the north. Kettlitz (1962) has estimated 2000 animals in the province, but subsequent assessments seem to indicate his figures to have been too low, as the species has been reported from additional districts not mentioned by Kettlitz.

The survey of game on farmland in the Orange Free State has shown the species still to be widespread though localized due to its habitat requirements. A total of 10619 animals was accounted for, though the figure has to be treated cautiously as a possible confusion with the mountain reedbuck by the farmers questioned cannot be ruled out. The largest concentration was to be found in the southern and eastern parts of the province (Von Richter, Lynch and Wessels 1972). A small population is protected in the Golden Gate Highlands National Park.

The range of the species has been reduced considerably in the past, mainly due to afforestation of the mountain sour grassveld along the escarpment and the Drakensberg. As this process still continues, more habitat suitable for the species will disappear. It seems, therefore, necessary to create additional reserves in the Transvaal, the Cape Province or the Orange Free State where the species still occurs in reasonable numbers.

Status: Rare (endemic).

\section{Reedbuck (Redunca arundinum)}

This species is in a precarious state of survival. The Kruger National Park protects the only large population in the Transvaal, estimated as 1860 in 1968 (Pienaar 1969). Even there the situation is viewed with concern as the preferred habitat has decreased in the past, due to bush encroachment and progressive desiccation of the range (Pienaar 1969; 
Jungius 1971). The largest population in a provincial reserve is to be found in the Loskop Dam Nature Reserve (54 in March, 1969) while 13 animals in all have been reported from the Hans Merensky and Percy Fyfe Nature Reserves. The population in the Loskop Dam Nature Reserve has not increased as it should, probably because suitable habitat is lacking. Remnant populations have been reported on the large private reserves and on a number of farms in the eastern Transvaal. The stronghold of the species in the Transvaal appears to be the Letaba, Pilgrims Rest and Barberton districts. The numbers on farmland probably will not exceed 1000 in the Transvaal.

In Natal the largest concentrations are found in the Umfolozi Game Reserve, the False Bay Nature Reserve, St Lucia Game Reserve and Giant's Castle Game Reserve. Small populations are preserved in a number of other reserves in Natal. From the Natal Midlands appreciable numbers are still recorded.

In the Cape Province the species has been virtually exterminated. A few animals survive in the Mountain Zebra National Park, the Bontebok National Park and the Addo Elephant National Park. However, in all these parks suitable habitat is so limited that they never can serve as a potential sanctuary for the species. Small numbers have been reported from the Umzimkulu divisions of the Transkei on forestry grounds, where they are protected. The only confirmed record on farmlands in the eastern Cape comes from Kokstad and King William's Town areas, where small groups still survive. Bigalke et al. (1962) reported the species from the Komga and East London division. Recent information indicates that the animals from the Komga division have since disappeared. No information could be obtained on the situation in the East London area.

Reedbuck have been recorded in historical times in the Orange Free State (Du Plessis 1969). A number have been re-introduced into the Golden Gate Highlands National Park, where suitable habitat is very limited. In 1970 they were believed to have died out. One doubtful record was obtained from the Reitz district in the eastern Free State (Von Richter et al. 1972). In South West Africa the species has been reported along the Okavango river and in the western and eastern Caprivi (Bigalke 1958; Tinley pers. comm.; Rautenbach pers. comm.). With the exception of the Caprivi, the species is virtually extinct. However, none of these areas enjoy conservation status and may be lost entirely in the near future due to proposed development.

The main danger to the survival of the species lies in the destruction of suitable habitat. Protection on farmlands by the owners certainly will help prolong the survival of the species, but if it is not coupled with proper range management, the ultimate extermination will not be stopped. In the reserves where the species occurs, great attention should be paid to the fact that suitable reedbuck habitat is maintained and where possible, former habitat re-claimed. This would also greatly benefit other sensitive grazing species.

It is, therefore, urgently required that additional sanctuaries are established in proper habitat, where the species still occurs or can be 
re-introduced with a reasonable assurance that the animals will establish themselves successfully.

Status: Rare, endangered in South Africa.

\section{Red lechwe (Kobus leche)}

This species is confined to the western and eastern Caprivi (Tinley pers. comm., Rautenbach pers. comm.) and the Okavango area (Bigalke 1958). In the eastern Caprivi numbers have drastically declined during the recent past mainly due to habitat destruction and indiscriminate hunting (Child and von Richter 1969). No formal conservation area has been set aside for the species in South West Africa, though it is protected in the Moremi Game Reserve and the Chobe National Park in Botswana. The latter reserve has a common boundary with the eastern Caprivi along the Chobe River and the population has to be considered as one, crossing the river seasonally. The lack of protection in the eastern Caprivi, therefore, has also had an adverse effect on the conservation of the species in the Chobe National Park.

The species range has been generally reduced by desiccation of suitable habitat in Ngamiland and has been exterminated locally. The creation of a sanctuary in the Caprivi for the species would be highly advisable.

Status: Rare, endangered in South Africa.

\section{Puku (Kobus vardoni)}

Tinley (pers. comm.) assumes that the puku occurs in the western Caprivi, since it is reported on the Angola side in the north and the Botswana side in the south. In the eastern Caprivi the puku has been exterminated in the last decade (Rautenbach pers. comm.; Child et al. 1969). The only sanctuary south of the Zambezi is found in the Chobe National Park where numbers probably do not exceed 100 (Child et al. 1969).

If the occurrence of the species in the western Caprivi is confirmed, all efforts should be made to protect them there.

Status: Rare, endangered - extinct in South Africa.

\section{Sable (Hippotragus niger)}

The species has to be considered in danger of extermination in South Africa.

The major stronghold in the Republic is the Kruger National Park where the 1969 count yielded 1068 animals. In three Transvaal provincial reserves small herds have been re-introduced. The Hans Merensky Game Reserve harbours the largest herd, 55 in January 1971, followed by the Loskop Dam Nature Reserve, 43 in January 1971, and 16 in the Percy Fyfe Nature Reserve in January 1971. The oldest established herd is to be 
found in the Loskop Dam Nature Reserve, while the other two populations represent recent introductions.

The high numbers in the Hans Merensky Game Reserve are the result of repeated introductions from farmland. Both other herds have more or less maintained their numbers. Bush encroachment in the Hans Merensky Game Reserve has rendered substantial parts of the reserve unsuitable for the species. Small numbers are still to be found in the Letaba and Pilgrims Rest districts of the eastern Transvaal Lowveld on large cattle ranches and some private reserves. Efforts to re-introduce or maintain the species on three large private reserves failed, due to lack of suitable habitat. Lambrechts (1974) estimated the numbers on framland as approximately 680 , with the highest concentrations in the Letaba, about 560, and Pilgrims Rest districts, about 70.

In the western and eastern Caprivi the species has been reported by Tinley (pers. comm.) and Rautenbach (pers. comm.) as very rare in the latter area. In South West Africa the species is nearing extinction. No conservation area exists in any of those areas.

The sable antelope, very sensitive in its habitat requirements, has suffered mostly as a result of changing vegetation due to past land use practices which have turned open savanna grassveld into bush. Older residents unanimously report that sable were once common throughout the Lowveld and describe the areas then inhabited by the species as open grassland. Pienaar (1969) also attributes the discouraging low numbers in the Kruger National Park to the increasing reduction of suitable habitat.

The creation of additional sanctuaries for sable antelope is urgently required. However, utmost care should be taken to acquire areas suitable for the species to ensure that proper breeding herds can be established. Consideration should be given to the acquisition of farm areas in the Lowveld where the species still occurs and every effort put into reclaiming proper habitat. The fact that the species still survives on those farms is taken as an indication that partially suitable habitat is still available. If this should not be feasible, then land should be acquired in the former range of the species and suitable habitat reclaimed prior to releasing the animals.

Status: Endangered in South Africa.

\section{Roan Antelope (Hippotragus equinus)}

This is the rarest antelope in South Africa and is on the verge of extinction.

The largest population is protected in the Kruger National Park and numbered 250 to 300 animals in 1970 (Joubert 1970). The centre of the population is found north of the Letaba River on the open grassland savanna west of the Lebombo Range.

The Transvaal Provincial Administration has caught a number of animals in the Waterberg district in the northwest, the only area in the Transvaal where the species still occurs on farmland, and has transferred them to the Percy Fyfe Nature Reserve. In December 1970, the herd 
numbered 16 animals and it is hoped to establish a breeding herd of this very rare antelope. The number of free-living animals has been assessed by Lambrechts (1974) as 80 on the New Belgium Block in the Waterberg district.

The only other wild populations are to be found in the western Caprivi (Tinley pers. comm.), along the Gwando River in the eastern Caprivi (Rautenbach pers. comm.) and around the Aha Mountains in the northeast of South West Africa. The South West African Administration transferred 75 animals from the Aha Mountains to the southwestern section of the Etosha Pan National Park in an effort to establish the species in a conservation area.

The rapid decline of the species throughout its former range in South Africa is largely attributable to the deterioration of open grassland savanna. Roan antelope have disappeared from parts of the Kruger National Park where they used to be common and the status of the species here is viewed with particular concern. Drastic changes in vegetation have very seriously limited suitable habitat, bush encroachment rendering these areas unsuitable (Pienaar 1969; Joubert 1970), thus adversely affecting this very sensitive grazing species. Moreover, it is susceptible to anthrax (Pienaar 1963, 1969; Joubert 1970).

In the Kruger National Park and in other conservation areas, management should aim at re-claiming and maintaining proper habitat for the species, as otherwise the future of the species is in very great jeopardy. Status: Endangered in South Africa.

\section{Black wildebeest (Connochaetes gnou)}

A once plentiful species, black wildebeest came near to extinction at the turn of the century, but has responded very well to protection measures. During 1970, 3100 individuals were accounted for, of which just under half are protected in major game reserves, the remainder being distributed on private lands (Von Richter 1971). The largest population is to be found in the Willem Pretorius Game Reserve in the central Orange Free State, numbering 443 in August 1970. Small herds have also been introduced outside the former range, or on marginal habitat within it, especially at high altitude in the Drakensberg.

The survival of the species may be considered as secure, as the surviving populations in conservation areas are expanding. However, the policy of distributing animals in twos and threes to farms and small municipal reserves should be discontinued and attempts made to give herds of 15 to 20 animals to institutions and farms where the establishment of proper breeding herds can be assured.

Black wildebeest and other species once occurred in great numbers in the Karoo and the establishment of a large conservation area for these species in the Karoo is most desirable.

Status: Rare, but secure. 


\section{Bontebok (Damaliscus dorcas dorcas)}

Bontebok are found on a number of reserves and farms in the coastal areas of the southwestern Cape Province, the range it formerly occupied in historical times (Du Plessis 1969). They have also been introduced outside of their former range, for instance onto farms in the Harrismith district in the northeast Orange Free State and Grahamstown district in the eastern Cape Province. In spite of rigid protection, however, the subspecies numbered only 861 in 1969 (Millar pers. comm.).

Bontebok are predominantly grazers and it seems clear that the area presently occupied includes very little really suitable habitat. Most of this is classified by Acocks (1953) as macchia or coastal renosterbos, with little or no grass vegetation. In addition, most of the former grazing areas have either been ploughed or have been excluded from the conservation areas. The species has therefore to subsist on somewhat inferior habitat. It is assumed that in the past the species were concentrated on the patches of grassy vegetation within the predominant macchia and renosterbosveld, such as that mapped by Acocks north of Swellendam.

About half of the present population is preserved in three reserves, while the remainder are protected on private farmland, the biggest herds being found in the Grahamstown and Harrismith districts, respectively 70 and 33 in 1970. Two of the reserves show little or no grass vegetation and here bontebok compete with other grazing species. Both reserves are considered marginal for the species. The third reserve, Bontebok National Park, has a more suitable vegetation (Grobler and Marais 1967), but here bontebok again has to compete with other grazing species and it is clear that the population will outgrow its habitat in a few years time.

The species is not in immediate danger, but it is viewed with concern that no herd is preserved in an area with really suitable habitat. Moreover, the largest herds are concentrated together and an epizootic disease could severely jeopardise the survival of the species.

Serious consideration should be given to the acquisition of a suitable additional reserve. Two possibilities appear to exist. Land on which bontebok do not occur could be purchased now and the veld allowed to recover to suitable bontebok habitat. Alternatively, farms which still harbour the species could be purchased. The distribution to suitable farms of proper breeding nuclei would also be a useful additional safeguard.

Status: Endangered.

\section{Tsessebe (Damaliscus lunatus)}

The majority of the present tsessebe population is confined to the Kruger National Park north of the Letaba River (Pienaar 1963) and the latest count yielded 584 animals. The second largest population is preserved in the provincial Percy Fyfe Game Reserve. This herd, 42 in December 1970, has increased very satisfactorily since the first introduction of the animals in 1966. A herd of 16 animals introduced into 
the Hans Merensky Game Reserve, on the other hand, has failed to increase, the population being adversely affected by scarcity of suitable habitat.

In the Timbavati Private Nature Reserve in the eastern Transvaal, a small herd has established itself despite heavy predator pressure. The suitable habitat available to this herd is very limited, however, and it is feared that the population will not be able to increase much further, unless habitat management is carried out.

Lambrechts (1974) has estimated 570 animals on farmland in the Transvaal, about 350 of which he found in the Pilgrims Rest district. With the expected increase in bush encroachment in the district, these numbers will be very drastically reduced if drastic measures are not adopted to reverse the trend.

In South West Africa the species is confined to the eastern and western Caprivi Strip (Tinley, Rautenbach pers. comm.) and to the Okavango territory and the area around the Aha Mountains. A recent estimate puts the numbers at between 50 and 100 , exluding the Caprivi. No conservation area, however, exists to protect the species in South West Africa.

It is considered of urgent importance to establish additional conservation areas for the species in suitable habitat in the Transvaal to avoid the danger of the species becoming extinct. In the established reserves all efforts should be made to reclaim and improve the preferred habitat. Management policies should focus primarily on the requirements of this very rare grazing species. In South West Africa a sanctuary is urgently required for the species and efforts should be made to obtain suitable areas for conservation.

Status: Rare; endangered in South Africa.

\section{Black-faced impala (Aepyceros melampus petersi)}

The subspecies has a very limited distribution north and south of the Cunene River, but also occurs in several other localities, some of them very isolated, in the Kaokoveld (Joubert 1971a). This author estimates the total number to be between 750 and 1000 animals, 750 probably being more accurate.

No conservation area exists in the main range of the subspecies. In the Etosha Pan National Park some 25 animals are protected around Namutoni in the east and an additional 100 or so animals were introduced in the west of the park where the subspecies formerly occurred. This herd now numbers around 150 . Unless suitable conservation areas are created, either along the Cunene River or in the Kaokoveld, the majority of the population is doomed to extinction. The Kaokoveld also includes suitable habitat for other endangered Southwest African species, such as Hartmann's mountain zebra and black rhinoceros.

Status: Endangered. 


\section{Klipspringer (Oreotragus oreotragus)}

Because of its habitat requirements - rocky outcrops and hills - the distribution of the klipspringer is rather patchy and localised. The somewhat inaccessible habitat should be a natural protection but evidently it is not, as klipspringers are becoming more and more rare throughout their range. In the Transvaal, the only large population is confined to the Kruger National Park. The provincial Loskop Dam Nature Reserve, Blyde River Nature Reserve, Ohrigstad Dam Nature Reserve, Hans Merensky Game Reserve and Rustenburg Game Reserve all harbour populations, the numbers being determined by the available habitat.

The species is found on private land where suitable habitat and sufficient protection is available. In general, however, its survival gives cause for concern.

In Natal the species only occurs in any reasonable numbers in the Giant's Castle Game Reserve, the Royal Natal National Park, and in forest reserves in the Drakensberg. Other game reserves in the Drakensberg harbour only small populations on limited habitat. Hluhluwe and Umfolozi Game Reserves have only very sparse habitat and accordingly the species is extremely rare there. It has been locally reported in small numbers from northern Natal and along the Drakensberg on farmland. In all the game reserves in the Drakensberg, with the exception of the Royal Natal National Park, numbers are reported to be declining in spite of rigid protection.

In the Cape Province the species is protected in the Mountain Zebra National Park and in a number of Forest Reserves where suitable habitat occurs. It is still widespread along Cape mountain ranges and in the hilly country further inland and occurs in reasonable numbers in this habitat (Fairall in litt.).

In the Orange Free State small populations have found refuge in the Willem Pretorius Game Reserve and the Golden Gate Highlands National Park. On farmlands the species has been reported in low numbers from the eastern, southeastern, and southern mountainous parts of the province. The total number for the whole province was assessed at 222 in 1970 (Von Richter et al. 1972).

In South West Africa the species is still quite widespread in suitable habitat. The only large population is protected in the Naukluft Mountain Zebra Park. In the Namib Desert Park and the Etosha Pan only small populations are encountered due to limited habitat.

The species is not threatened with immediate extinction but is certainly not fully safeguarded for the future. Consideration should be given to the creation of additional sanctuaries, especially in the Cape Province, the Orange Free State and South West Africa.

Status: Rare.

\section{Oribi (Ourebia ourebi)}

The species is an inhabitant of the open grassy plains of the Southern 
Savanna zone, and its distribution is often localised (Ansell 1968). Its overall distribution in South Africa has been much modified and reduced by human activity, notably vegetation changes and heavy hunting pressure.

The species has been re-introduced into the Loskop Dam Nature Reserve and Ohrigstad Dam Nature Reserve. In both areas, however, the species is merely holding its own. A re-introduction in the Kruger National Park failed. Small populations have been reported from the provincial reserve Blyde Rivierspoort, from a municipal and from a private reserve outside Pretoria, and from the Lydenburg Nature Reserve. Forest reserves with sufficient habitat in the eastern and southeastern Transvaal also harbour small populations. On farmlands, oribi have been reported from the southeastern Highveld (Ermelo, Wakkerstroom, Piet Retief and Carolina as the centre of their present distribution). Small numbers also still occur on the central Highveld and on mountain sour grassveld along the escarpment.

In the Cape Province a recent detailed survey has revealed only 370 animals to have survived on farmland in the southeastern Cape Province (Millar 1970b). The highest concentrations of these are to be found in the Bathurst, Mount Currie and Humansdorp Divisions. The species also still occurs around Umzimkulu and Matatiele but no figures could be obtained for these areas. The Department of Forestry protects at present probably the largest population in the Umzimkulu Division, where the establishment of a reserve is under negotiation. The two municipal reserves at Matatiele and Queenstown harbour three oribi in all.

In Natal the species is now confined to the foothills of the Drakensberg range and the Natal Midlands. It formerly occurred in Zululand, but has long since disappeared from there (Vincent 1970). Giant's Castle Game Reserve harbours probably the largest population not only in Natal, but in the whole of South Africa. In all the other reserves along the Drakensberg range the species has been reported in fair numbers, but lack of sufficient habitat or the size of the reserves have limited numbers.

A recent survey in the Orange Free State has put the number of oribi as low as 314 , the highest concentration being in the Harrismith, Bethlehem, Reitz and Frankfort districts in the northeast (Von Richter et al. 1972). In South West Africa the species is confined to the Caprivi strip and the Okavango territory (Bigalke 1958; Tinley pers. comm.; Rautenbach pers. comm.) However, no conservation area exists in these territories.

With the possible exception of Natal, the species is in a very precarious state of survival. The cause of the decline can probably be sought in ecological habitat changes brought about by human activities, for instance by intensive agriculture and the afforestation of mountain sour grassveld, especially in the Transvaal and Natal. Coupled with human activities, is increased illegal hunting pressure. Millar (1970b) -lists 11 reasons for the decline of the species which he elicited from the farming community.

The establishment of suitable conservation areas for oribi in the Transvaal, the Cape Province, the Orange Free State, and South West Africa is considered of utmost importance. In conservation areas where oribi are already protected, management policy should aim at providing 